"SDG 3 and financing instruments in Austria and Ukraine: Challenges and perspectives"

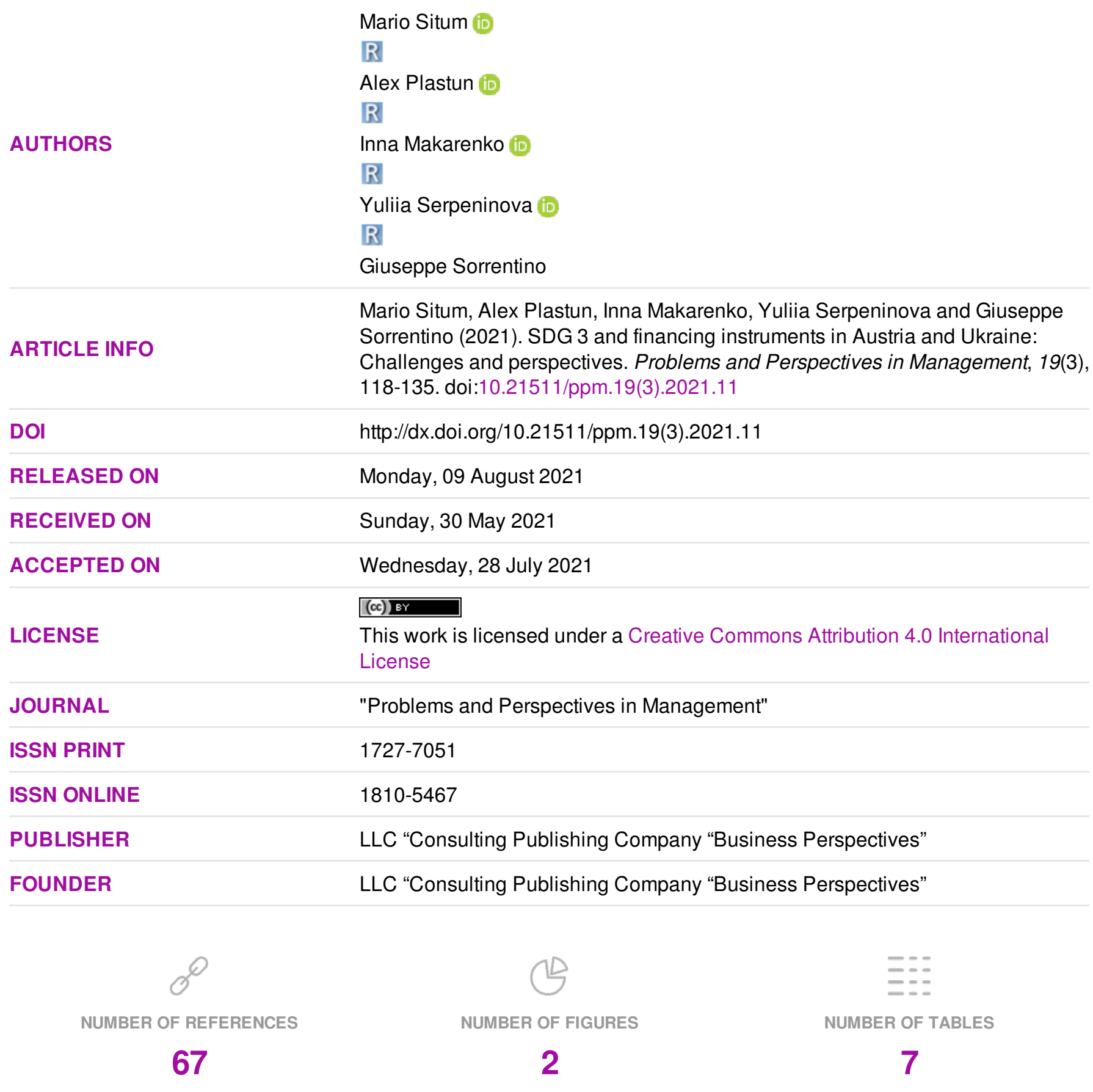

(C) The author(s) 2021. This publication is an open access article. 


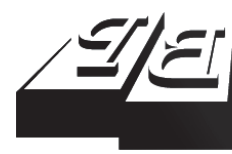

\section{BUSINESS PERSPECTIVES}

9

LLC "CPC "Business Perspectives" Hryhorii Skovoroda lane, 10, Sumy, 40022, Ukraine www.businessperspectives.org

Received on: $30^{\text {th }}$ of May, 2021 Accepted on: $28^{\text {th }}$ of July, 2021 Published on: $9^{\text {th }}$ of August, 2021

(C) Mario Situm, Alex Plastun, Inna Makarenko, Yuliia Serpeninova, Giuseppe Sorrentino, 2021

Mario Situm, Doctor of Economics, Professor, Chair of Business Management and Corporate Restructuring Studies, University of Applied Sciences Kufstein, Austria.

Alex Plastun, Doctor of Economics, Professor, Chair of the International Economic Relations, Sumy State University, Ukraine. (Corresponding author)

Inna Makarenko, Doctor of Economics, Associate Professor, Chair of Accounting and Taxation, Sumy State University, Ukraine.

Yuliia Serpeninova, Ph.D., Associate Professor, Chair of Accounting and Taxation, Sumy State University, Ukraine.

Giuseppe Sorrentino, M.Sc., Research Assistant, University of Applied Sciences Kufstein, Austria.

Funding data:

Financed equally from the Austrian Federal Ministry of Education, Science and Research and the Ministry of Education and Science of Ukraine

Mario Situm (Austria), Alex Plastun (Ukraine), Inna Makarenko (Ukraine), Yuliia Serpeninova (Ukraine), Giuseppe Sorrentino (Austria)

\title{
SDG 3 AND FINANCING INSTRUMENTS IN AUSTRIA AND UKRAINE: CHALLENGES AND PERSPECTIVES
}

\begin{abstract}
This study aims to conduct a comparative analysis of the SDG in healthcare achievement in Austria and Ukraine and to determine possible lessons for Ukraine based on best EU and world experiences. To identify existing challenges and perspectives a comparative analysis of key indicators of healthcare expenditures and health financing systems in Austria and Ukraine was carried out. Results indicate that in Ukraine there is a substantial lack of public funding for healthcare (only 682 US dollars per capita in 2018), a poor share of voluntary health insurance (less than 1\%), significant amounts (on average 50\%) of expenditures of the population in general spending on health. On the contrary, in Austria, there is sufficient public funding for healthcare (5,879 US dollars per capita in 2018), more than $5 \%$ share of voluntary health insurance, moderate amounts (on average 25\%) of expenditures of the population in general spending on health. Austria's experience as an EU-member country with a successful example of a financing strategy for the healthcare system is a sound example for Ukraine. The alternative financing tools (e.g. result-based financing, impact investment, public-private partnership) can be used as an additional financing mechanism of healthcare funding in Ukraine. The use of these instruments along with the improvement of the fiscal policy, social security, and governance based on Austrian experience can cut the existing financing gap to achieve SDG targets in healthcare in Ukraine.
\end{abstract}

\section{Keywords}

JEL Classification

\section{INTRODUCTION}

Sustainable Development Goal (SDG) 3 "Ensuring healthy lives and promoting well-being at all ages" has the central place among other SDGs and intensive consideration of the SDG 3 targets is relevant because their achievement is considered crucial to be able to achieve other SDG targets as well (Guégan et al., 2018; Nunes et al., 2016). The World Health Organization (2020b) reports that access to health services improved from 2000 to 2017, with the strongest increase in low-and lower-middle-income countries. The global COVID-19 pandemic caused many new challenges to overcome and pose a huge risk of global health targets' achievement (Lee \& Kim, 2021). Access to new technologies and knowledge and innovative development of healthcare institutions are important to achieve SDG 3 successfully (Grynko et al., 2020).

To ensure the progress for SDG 3 it is essential to provide a sufficient pool of investment resources (Buse \& Hawkes, 2015). The required amount to achieve the SDG 3 targets by 2030 is estimated at an additional US $\$ 371$ billion per year; even with projected growth in health spending, the funding gap at US\$20-US\$54 billion per year still would remain (United Nations Development Programme, 2020). 
This underscores the relevance of the development of investment tools for financing SDGs and the SDG 3 in particular, as well as the need to pursue new and innovative approaches and tools on a responsible basis (Bhutta et al., 2020; Siddiqi et al., 2020). According to the Sustainable Development Report 2019 (Sachs et al., 2019), Ukraine ranks $41^{\text {st }}$ and Austria ranks $5^{\text {th }}$ place out of 162 countries in the overall level of SDGs achievement. The overall level of SDG-3 achievement in Austria is 94.9 out of all 100 targets, in Ukraine it is only 71.8. Austria's healthcare system is considered a symbol of prosperity and well-being of this country and has a funding share of $11.1 \%$ of GDP (Statistik Austria, 2020b) as opposed to 3.2\% in Ukraine (World Health Organization, 2020a). Austria is one of six countries worldwide that have explicitly mentioned the SDGs in their budget documentation (Sachs et al., 2019). In this context, Austria's experience as an EU-member country with a successful example of SDGs-financing strategy for the healthcare system is undoubtedly the best example for Ukraine.

Based on Christ and Burritt (2019), and Fryatt et al. (2017), sharing experiences between countries is an essential criterion for achieving Universal Health Coverage (UHC) more efficiently and quickly, but also to explain the reasons for weak and inequitable health (Di Ruggiero, 2019; Tamsma \& Costongs, 2018). This study is a first attempt to describe the possible transfer of successful concepts from one country to another to achieve the SDGs and close the existing research gap. In particular, a comparison between Austria and Ukraine indicates that Ukraine has the potential to increase target achievement in the area of SDG 3, but needs the implementation of best practices and Austria can be an efficient example.

\section{LITERATURE REVIEW}

The issues of healthcare and its financing are intensive objects of attention among academicians. According to the Scopus database, there is a constant growth of publications during the last five years (see Figures 1 and 2) dedicated to healthcare funding (8,286 publications worldwide) and in particular SDG 3 funding. Still, despite the positive dynamics on publication activity devoted to SDG 3 funding, it is obvious that this research area needs further development (which is less than $1 \%$ of the overall number of papers devoted to healthcare funding).

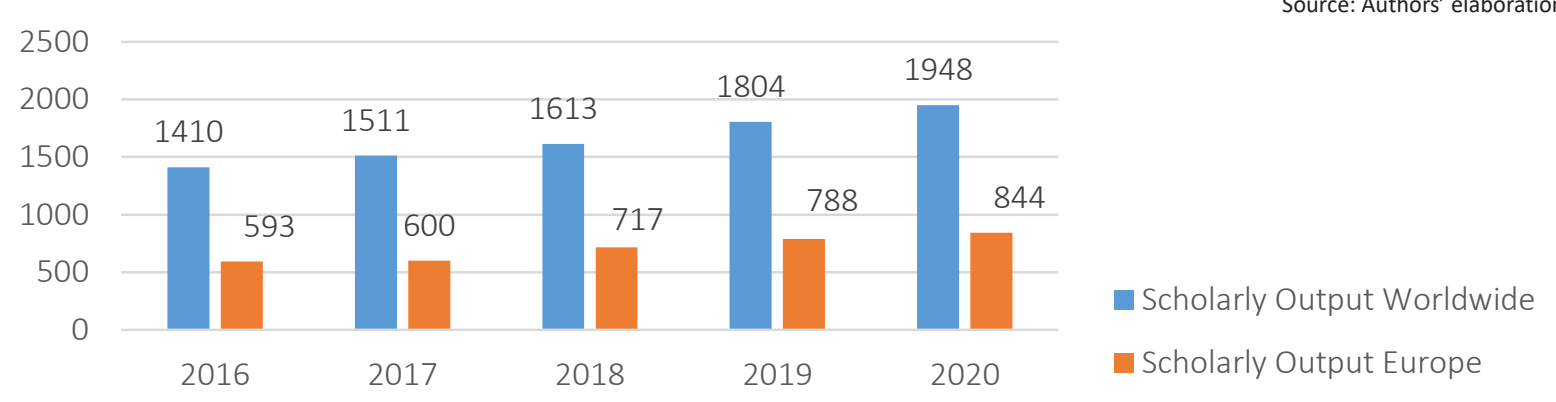

Figure 1. Number of publications in the Scopus database under the research area "healthcare funding" for 2016-2020

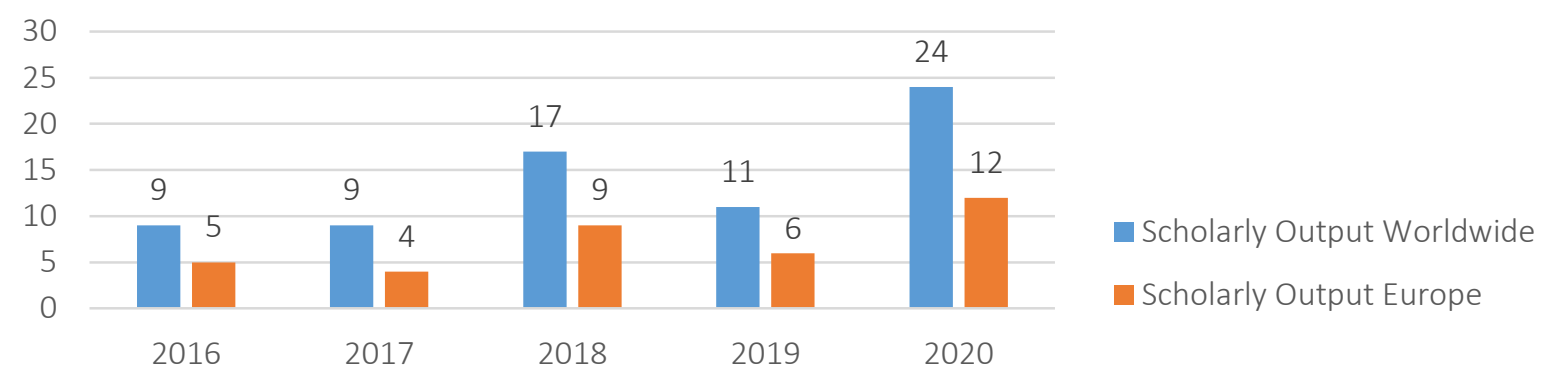

Figure 2. Number of publications in the Scopus database under the research area "SDG 3 funding" for 2016-2020 
Thus, there is a research deficit in the outlined research field, although target achievement in SDG 3 presumes financial support. Stenberg et al. (2017) stated that all countries need to strengthen investments in healthcare through prioritizing equitably, strategic planning to implement a national path towards SDG 3 goals achievement. Dieleman et al. (2018) projected the huge differences in expected future health spending per capita: as estimated high-income countries will spend 45 times more on health care services per capita than low-income countries. To ensure that no nation is left behind it is essential to learn and share the experiences and knowledge in low- and middle-income countries throughout the course of implementation (Cerf, 2019). Advanced economies had a satisfactory level of sustainability; while the level of SDI of the emerging markets was lower (Koilo, 2020). Plastun et al. (2021) showed that implementation of the best practices can speed up SDGs achievement. Melnyk et al. (2013) discussed innovative strategies to speed up the transformation of the traditional economy towards sustainability as well as the use of digital technologies.

There are different approaches for the estimation of the additional spending on health towards the SDG 3 targets (Table 1). However, all the scholars highlight the existing financing gap and the need for additional financing sources to exhilarate the progress of SDG 3 targets achievement.

Table 1. Estimated additional spending per year on health required by 2030 to achieve progress within the SDG 3 health targets

\begin{tabular}{l|c}
\hline \multicolumn{1}{c|}{ Source } & Estimated financing gap \\
\hline Stenberg et al. (2017) & $\begin{array}{c}\text { US\$371 billion (ambitious } \\
\text { scenario) }\end{array}$ \\
\hdashline $\begin{array}{c}\text { Doumbia and Lauridsen } \\
\text { (2019) }\end{array}$ & US $\$ 274$ billion (progress \\
scenario) \\
\hline $\begin{array}{l}\text { Schmidt-Traub and Shah } \\
(2015)\end{array}$ & US $\$ 68-87$ billion \\
\hdashline $\begin{array}{l}\text { Development Initiatives } \\
(2020)\end{array}$ & US $\$ 274$ billion** \\
\hline
\end{tabular}

Note: * in 2013 US \$, ** adjusted from Jamison (2018) and Stenberg et al. (2017) in 2018 US\$.

According to the International Bank for Reconstruction and Development and The World Bank estimates (2019), on average 20-40\% of health funding worldwide is misused or wasted.
Bali and Taaffe (2017) suggested that for many countries, increasing financial support to achieve the SDG 3 targets can be realized through private sector engagement and domestic resource mobilization and allocation.

Among a wide range of existing financing instruments, including though on the responsible basis to achieve SDG 3 targets one of the most recommended is a public-private partnership (Wang \& Ma, 2020; Cerf, 2019). Based on Wang and Ma's (2020) comprehensive literature analysis, public-private partnership is the most sustainability-oriented instrument related to the healthcare sector. The search for additional sources - other than government shares of GDP - to finance the national healthcare system appears essential based on the study by Bennett et al. (2020). In the extensive survey of experts, it was found that government financing of the healthcare system and the financial shocks to healthcare spending that have historically occurred are key challenges. This affects the expansion of health coverage, which jeopardizes the achievement of Goal 3.8.1 (Achieve universal health coverage).

The national particularities of healthcare financing approaches are widely represented in the scientific community in Ukraine and Austria. Malyovanyi et al. (2019) state that due to the chronic lack of budget funds Ukraine should additionally spend up to 43.4 billion US dollars per year to reach developed countries. While describing impact-investing as an effective tool for building socially responsible state investment policy in Ukraine Yelnikova and Kwilinski (2020) indicate the key barriers on the way of effective development of impact-investing in health care in Ukraine. Among other challenges of alternative sources of health financing in Ukraine, one can mention the unpreparedness of municipal authorities to provide guarantees of funds' return to private partners within the frames of implementing the public-private partnership approach in Ukraine (Popova et al., 2020). Bachner et al. (2018) analyzed the Austrian health system including developments in organization and governance, healthcare financing and provision, healthcare reforms, and healthcare system performance. Griebler et al. (2010) investigated the metanalysis of the challenges of SDGs implementation in Austria. Theurl (2019) 
focused on the public part of the Austrian health sector. It was indicated that the compulsory health insurance system in Austria (as part of the social insurance system) covers the health care costs of nearly all of the population.

The Austrian Council of Ministers decided in January 2016 that the SDGs would be integrated into all ministries' strategies and relevant programs. This means that the SDGs are generally recognized and taken into account as relevant guidelines at the national level (mainstreaming-approach) (Organisation for Economic Co-operation and Development, n.d.; United Nations, 2020). Moreover, they are integrated into all activities of Austrian politics and administration and have since been pursued in a targeted and effective manner (Bundeskanzleramt, 2020 , p. 16). The SDG 3 targets are taken into account in the Austrian health targets and via the health promotion strategy within the framework of the target steering health. To ensure that all activities of the individual ministries can be coordinated efficiently, an interministerial working group has been set up, which is headed by the Federal Chancellery and the Federal Ministry for European Affairs, Integration and Foreign Affairs. (Griebler et al., 2020, p. 1; United Nations, 2020).

SDG 3 targets incorporation into national strategic documents in Ukraine estimated on the low level $(43 \%)$ and there are not officially approved plans of SDGs 3 targets implementation as well as financing strategy of their achievement. Among main problems connected with the SDG 3 targets incorporation into national strategic documents in Ukraine are the following: lack of an efficient system of reforms planning; lack of public monitoring; insufficient level of accountability; weak corresponding of tasks distribution among national authorities; absence of evaluation process of necessary financial resources for their implementation etc. (Horokhovets et al., 2017).

A possible explanation for this is that in Austria all ministries are tasked with pursuing the SDG goals, whereas in Ukraine the activities are bundled in a special ministry. There are no studies in the literature that have investigated the con- nection between the political and administrative integration of the SDG targets and the degree of target achievement. However, a connection can be assumed, which may explain part of the better ranking of Austria compared to Ukraine. Possible evidence for this is provided by Bhutta et al. (2020), Fryatt et al. (2017), and Nabukalu et al. (2020), who showed that effective strategies to strengthen governance, improved synthesis of information, improved coordination between institutions or structural reforms can lead to improved SDG target achievements.

This study, using a comparative analysis of the SDG 3 progress in Austria and Ukraine, aims to determine possible solutions to boost SDG 3 achievement in Ukraine based on best in breed practices.

This leads to the following research questions for this paper:

- What are the main differences in the degree of target achievement with regard to SDG 3 between Austria and Ukraine and how these differences can be explained?

- To what extent do the financing sources of the SDG 3 targets differ between the two countries?

- What conclusions can be drawn from the Austrian experience for Ukraine and what recommendations can be given for political decision-makers?

- What alternative financing mechanisms can be used as a source of SDG in healthcare funding?

\section{DATA AND METHODOLOGY}

The data for the national particularities of SDG 3 in Austria and Ukraine were taken from the Voluntary National Reviews and Monitoring Reports on SDGs (Ministry of Economic Development, Trade and Agriculture of Ukraine et al., 2020; Statistik Austria, 2020a). The comparative analysis on national SDG 3 targets and indicators shows that Austria's national targets corre- 
spond exactly to those of the globally defined targets. As for the Ukrainian national SDGs 3 targets, not all of them are agreed with the global ones.

Next, an assessment of progress in achieving targets of SDGs 3 in Ukraine and Austria according to national monitoring (in 2019) and global monitoring dynamics over the period 2017-2020 was made. Data for national monitoring were taken from the Monitoring Report on SDGs in Ukraine (Ministry of Economic Development, Trade and Agriculture of Ukraine et al., 2020) and Austrian national statistical services (Statistik Austria, 2020a; Bundeskanzleramt, 2020). The global monitoring corresponds to Sachs et al. (2017, 2018, 2019, 2020) and shows the dynamic and tendencies of SDG 3 achievement in both countries. The assessment of life expectancy in Ukraine and Austria in 2019 is based on the Global Competitiveness Report 2019 (Schwab, 2019).

The methodology of this paper includes the methods of comparative analysis, retrospective analysis, and benchmarking in order to analyze the longitudinal data in Austria and Ukraine in terms of dynamics of healthcare expenditures and SDG 3 implementation in both countries over the 20162020 period. The analysis of healthcare financing sources in Ukraine and Austria is based on the World Health Organization, National Health Service of Ukraine and Federal Ministry for Social Affairs, Health, Care and Consumer Protection in Austria. These data track healthcare expenditures (per capita and \% of GDP); government expenditure on health (per capita; as a share of current health expenditure; and as a share of general government expenditure); voluntary health insurance as a share of current health expenditure; and share of expenditures of the population in general spending on health.

Employing bibliometric analysis (via SciVal by Elsevier) the publications in the Scopus database dedicated to alternative financing tools in healthcare were analyzed. The approaches of healthcare financing according to United Nations Development Program (UNDP) and the United States Agency for International Development (USAID) we prioritized according to the number of publications in the Scopus database (as of 10.07.2021).

\section{RESULTS}

\subsection{Correspondence of national SDG 3 targets and indicators in Ukraine and Austria with the global ones}

The global targets are designed to specify concrete vectors of the SDGs at the global level. Based on the reports of Statistik Austria (2020b), it can be seen that Austria's national targets correspond exactly to those of the globally defined targets. As for Ukrainian national SDG 3 targets, it is necessary to confirm that not all of them are agreed with the global ones (Table A1). In Ukraine national SDG 3 targets 3.1-3.4, 3.6 meet the global ones and can be compared. National target 3.7. "Ensure universal, quality immunization with innovative vaccines" corresponds partly to the global 3.8 target concerning vaccination. The analysis of national SDG 3 in Ukraine shows that there are no corresponding targets to the global targets 3.5, 3.7, 3.9, and 3.b. These national tasks were not prioritized within SDG 3, but they are included in the relevant national state program documents. And there is only a partial correlation between national 3.9 "Reform health care financing" and global 3.c, which indicates some weaknesses in strategic financial planning.

Each target is concretized with indicators. These indicators serve as a basis for international comparison. There are big differences among national and global indicators in both countries. On the one hand, these indicators were designed to monitor national SDGs achievement and their comparison. On the other hand, many of these indicators are not comparable among different countries due to the capacities of the national statistical agencies. This can be seen particularly well in the comparison. Overall, it can be seen that significantly more indicators (37) are used in Austria than in Ukraine (16).

In this context, it can also be noted that in Ukraine there is always one indicator for each target/sub-target, which is used to measure the achievement of the target. In Austria, on the other hand, there is sometimes more than one indicator for certain goals/sub-goals. 
Specifically, this concerns objectives 3.4.1, 3.5.1, 3.7.2, 3.8.2 (2 indicators each), 2.5.2 (3 indicators), 3.a.1 (4 indicators) and 3.c.1 (6 indicators). This could be seen as an indication that the pursuit of the SDG3 goals is being pushed and monitored harder, which is probably the reason for Austria's good global positioning $\left(7^{\text {th }}\right.$ place in 2020).

For some national targets in Austria, no indicators are tracked, because the target was largely achieved. There is no 3.1.2 (Proportion of births attended by skilled health personnel), 3.3.3 (Malaria incidence per 1,000 population), 3.3.5 (Number of people requiring interventions against neglected tropical diseases), and 3.9.2 (Mortality rate attributed to unsafe water, unsafe sanitation, and lack of hygiene). As can be seen, the indicator framework in Ukraine has not yet been fully developed or adapted. This seems explainable in light of the findings of the Economic and Social Council of the United Nations, which explicitly states that the full development of the indicator framework is a process that takes time and must allow for the possibility of agreements because knowledge must be built up and data must be made available (United Nations, 2016). In addition, the explanation for the differences could also be that in both countries, there are different understandings in country-level implementation of what national development priorities are needed at the national level to enable full implementation of the SDGs (Abeykoon, 2021).

\subsection{Progress in national Ukraine/ Austria SDG 3 indicators achievement}

SDG 3 indicators allow to estimate the progress in concrete dimensions, identify weak places and serve as a base for comparison (Table 2).

There are 16 indicators within 9 SDG 3 targets in Ukraine. To date there are no indicators in Ukraine that are already achieved, only 7 out of 16 indicators are on the way to achievement, all the other indicators have a low probability of achievement or cannot be achieved with such a dynamic at all. For Austria, on the other hand, there is already a relatively high level of target achievement for many indicators and even full target achievement for certain targets. One of the most important points is certainly global target 3.8.1 (Achieve universal health coverage, including financial risk protection, access to quality essential healthcare services, and access to safe, effective, quality, and affordable essential medicines and vaccines for all) (Brolan \& Hill, 2015), which is not specified in this form in the Ukrainian national targets. This missing indicator is certainly to be seen as an important variable, which can also explain the rankings of the two countries.

\subsection{Global monitoring of SDG 3 in Ukraine and Austria}

Based on Chancel et al. (2018), the individual scores and the resulting rankings from Table 3 can be used to compare the performance of tar-

Table 2. The assessment of progress in achieving the targets of SDGs 3 in Ukraine and Austria according to national monitoring 2019

Source: Bundeskanzleramt (2020, p. 61), Ministry of Economic Development, Trade and Agriculture of Ukraine et al. (2020), Statistik Austria (2020a).

\begin{tabular}{|c|c|c|c|}
\hline \multirow{2}{*}{$\begin{array}{l}\text { Dynamics of indicators } \\
\text { by targets }\end{array}$} & \multirow{2}{*}{ Characteristics of progress } & \multicolumn{2}{|c|}{ SDG 3 Indicators } \\
\hline & & Ukraine & Austria \\
\hline Almost unfulfilling & $\begin{array}{l}<20 \% \text { cannot be achieved } \\
\text { with such dynamics }\end{array}$ & $\begin{array}{l}3.3 .1,3.5 .1,3.8 .1 \\
3.9 .1\end{array}$ & 3.3.4. \\
\hline Low probability of achievement & $\begin{aligned} 20 \% \leq \text { and } & <60 \% \text { needs significant } \\
& \text { acceleration }\end{aligned}$ & $\begin{array}{c}3.4 .1,3.4 .4,3.6 .2 \\
3.7 .1,3.8 .2\end{array}$ & - \\
\hline $\begin{array}{l}\text { Medium probability of } \\
\text { achievement }\end{array}$ & $60 \% \leq$ and $<80 \%$ needs some acceleration & - & 3.5.2., 3.a.1.* \\
\hline High probability of achievement & $\geq 80 \%$ on the way to achievement & $\begin{array}{c}3.1 .1,3.2 .1,3.3 .2 \\
3.4 .2,3.4 .3,3.5 .2 \\
3.6 .1\end{array}$ & $\begin{array}{c}\text { 3.1., 3.a.1.**, 3.3.1, 3.4.1.**, } \\
\text { 3.4.2.*, 3.6.1., 3.8.1. }\end{array}$ \\
\hline Largely achieved & up to $100 \%$ & - & 3.1.2, 3.3.3., 3.3.5., 3.9.2. \\
\hline
\end{tabular}

Note: $*$ and $* *$ refer to the designs in Table 3 . Since there are several targets with the same numbering, but the target achievements are not measured for all of them, these markings were introduced for correct and comprehensible representation. 
Table 3. The assessment of progress in achieving targets of SDGs 3 in Ukraine and Austria according to global monitoring in 2017-2020

\begin{tabular}{|c|c|c|c|c|c|c|c|c|c|c|}
\hline \multirow[b]{2}{*}{ Year } & \multicolumn{5}{|c|}{ Austria } & \multicolumn{5}{|c|}{ Ukraine } \\
\hline & Place & $\begin{array}{l}\text { SDG } \\
\text { index }\end{array}$ & $\begin{array}{l}\text { SDG3 } \\
\text { score }\end{array}$ & $\begin{array}{l}\text { SDG } 3 \\
\text { status }\end{array}$ & SDG 3 trend & Place & $\begin{array}{c}\text { SDG } \\
\text { index }\end{array}$ & $\begin{array}{c}\text { SD3 } \\
\text { score }\end{array}$ & $\begin{array}{l}\text { SDG } 3 \\
\text { status }\end{array}$ & SDG 3 trend \\
\hline 2020 & $7 / 166$ & 80.7 & n.a. & $\begin{array}{c}\text { Challenges } \\
\text { remain }\end{array}$ & $\begin{array}{c}\text { Moderately } \\
\text { increasing }\end{array}$ & 47/166 & 74.2 & n.a. & $\begin{array}{c}\text { Major } \\
\text { challenges }\end{array}$ & $\begin{array}{c}\text { Moderately } \\
\text { increasing }\end{array}$ \\
\hline 2019 & $5 / 162$ & 81.1 & 94.9 & $\begin{array}{c}\text { Challenges } \\
\text { remain }\end{array}$ & On track & $41 / 162$ & 72.8 & 71.8 & $\begin{array}{c}\text { Major } \\
\text { challenges }\end{array}$ & $\begin{array}{c}\text { Moderately } \\
\text { increasing }\end{array}$ \\
\hline 2018 & $9 / 156$ & 80.0 & 93.7 & $\begin{array}{c}\text { Significant } \\
\text { challenges } \\
\text { remain }\end{array}$ & On track & $39 / 156$ & 72.3 & 69.3 & $\begin{array}{c}\text { Major } \\
\text { challenges }\end{array}$ & $\begin{array}{l}\text { Moderately } \\
\text { increasing }\end{array}$ \\
\hline 2017 & $7 / 157$ & 81.4 & 93.8 & $\begin{array}{l}\text { Significant } \\
\text { challenges } \\
\text { remain }\end{array}$ & On track & $39 / 157$ & 72.7 & 67.0 & $\begin{array}{c}\text { Major } \\
\text { challenges }\end{array}$ & $\begin{array}{c}\text { Moderately } \\
\text { increasing }\end{array}$ \\
\hline
\end{tabular}

Note: * the overall score (SGD index) is defined as the arithmetic mean across all SDG scores.

get achievement between different countries. From the available surveys, it can be recognized that there is an inequality between Austria and Ukraine, which can be seen as a reason for political decision-makers to initiate appropriate measures to improve the situation in individual areas. However, based on Diaz-Sarachaga et al. (2018), it does not represent an accurate value for actually determining the extent to which the SDG targets have actually been achieved, because there are distortions in the calculation (e.g. limitations in collecting data of SDG indicators, missing information, etc.). Regardless of this fuzziness in the measurement, it can be concluded on the basis of the researched data that due to the lower degree of target achievement in Ukraine, there is also a lower international ranking.

The dynamics of progress in achieving targets of SDG 3 in Ukraine and Austria indicates that in 2017-2020 Austria always was in the top 10 among more than 150 countries, while Ukraine's position is mostly more than 40 in the general ranking. Both countries have made positive progress in achieving targets of SDG 3, but in comparison with Austria Ukraine, still has a moderately improving trend. There is no doubt concerning the need to reform the healthcare system in Ukraine, as it ranks $100^{\text {th }}$ in the world (among 141 coun- tries) in terms of life expectancy, Austria ranks $14^{\text {th }}$ place (Schwab, 2019).

\subsection{Comparative analysis of the Ukrainian-Austrian experience of SDG in healthcare funding}

Key indicators of healthcare expenditures in Ukraine and Austria show huge differences between the two countries, which are summarized in Table 5. Healthcare expenditures per capita in Ukraine are almost 9 times less in comparison with Austria (682 US dollars and 5,879 US dollars respectively), while general expenditure on health in Austria (46, 991 million US dollars in 2018) is almost 5 times more than in Ukraine $(10,105$ million US dollars in 2018). One of the possible financial sources of healthcare expenditures is voluntary health insurance. It was revealed that the share of voluntary health insurance in current health expenditure in Ukraine is less than $1 \%$ which is absolutely insufficient. It is worth mentioning that there is strong government support for healthcare financing in Austria. Government expenditure on health per capita in Austria in 2018 was 4,297 US dollars, which is 13 times more than in Ukraine (327 US dollars).

Table 4. The assessment of life expectancy in Ukraine and Austria in 2019

Source: Schwab (2019).

\begin{tabular}{l|c|c}
\hline \multicolumn{1}{c|}{ Index } & Ukraine & Austria \\
\hline Healthy life expectancy years score & $65.6 / 100$ & $95.1 / 100$ \\
\hline Healthy life expectancy years rank & $100 / 141$ & $14 / 141$ \\
\hline
\end{tabular}


Table 5. Key indicators of healthcare expenditures in Ukraine and Austria in 2018

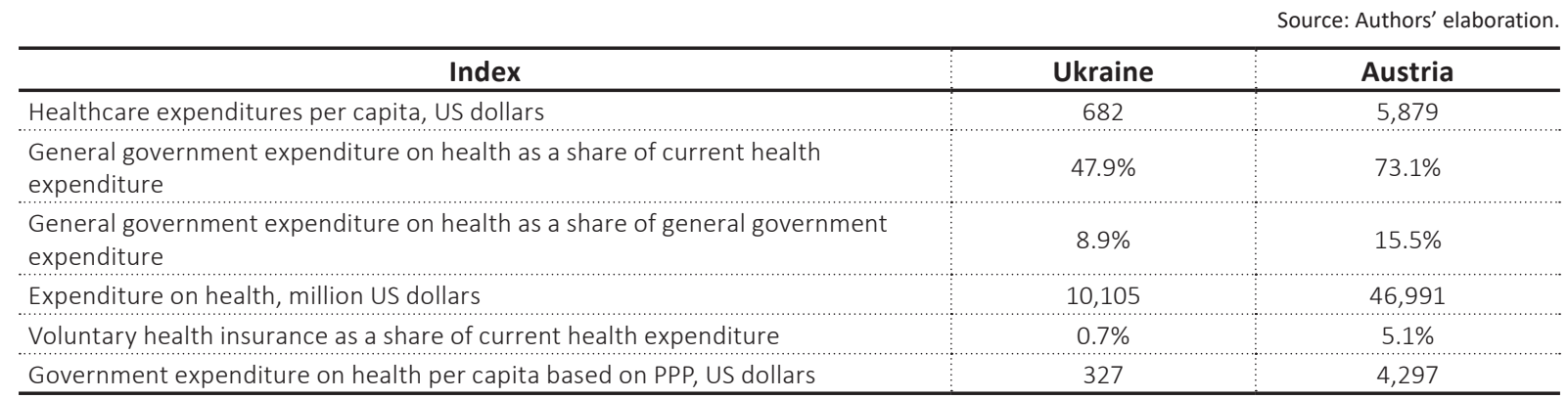

Providing the health sector with sufficient funding (as well as the efficiency of use) largely determines the effectiveness of health reforms implementation. From this perspective, the EU experience for Ukraine is crucial. In Ukraine, the corresponding to the global target 3.c. "Substantially increase health financing" is target 3.9. "Reform health care financing" and basically indicator 3.9.1. "Share of expenditures of the population in general spending on health". To achieve this target health care financing reform provides several complex tasks such as "financing of primary care using the standard per capita, defining a guaranteed package of services", "financing of specialized care according to the principles of the global budget" (Horokhovets et al., 2017).

According to the 2020 Voluntary National Review, the benchmark of SDG 3 indicator number 3.9.1. for Ukraine is 35\% for 2025 and $30 \%$ for 2030 . However, the actual dynamics indicates the huge gap between recent da-

Source: Statistik Austria (2020b), World Health Organization (2020a), Ministry of Economic Development, Share of expenditures of the population in general Trade and Agriculture of Ukraine et al. (2020).

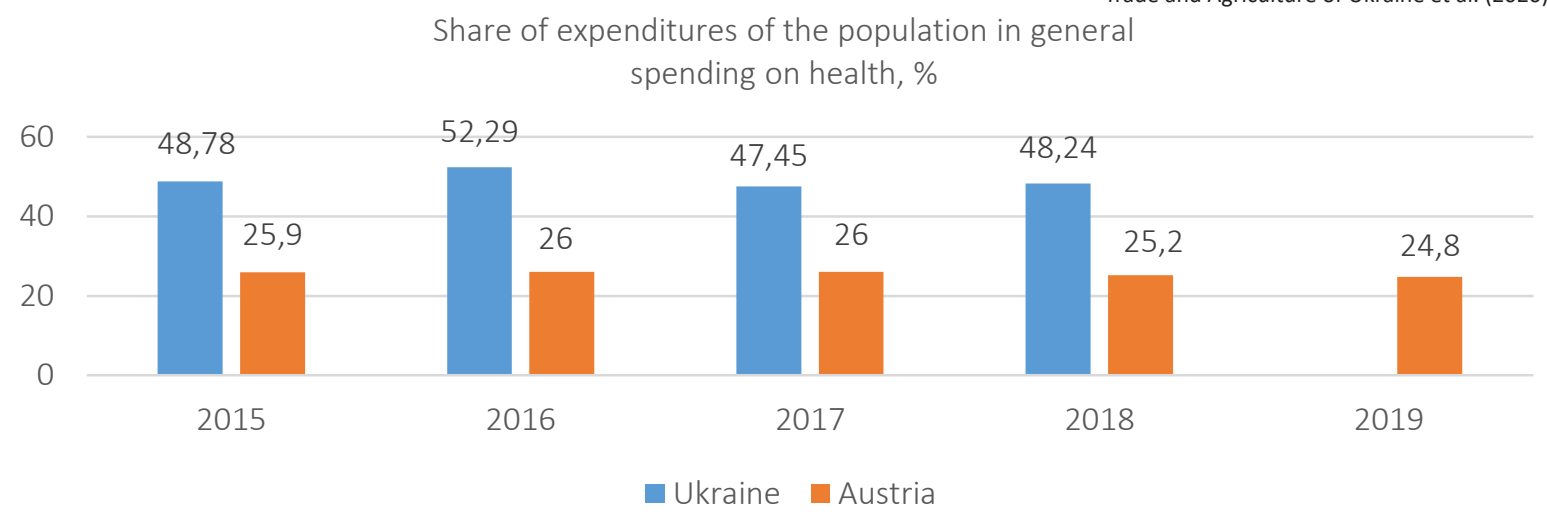

Health expenditure

(\% of GDP)

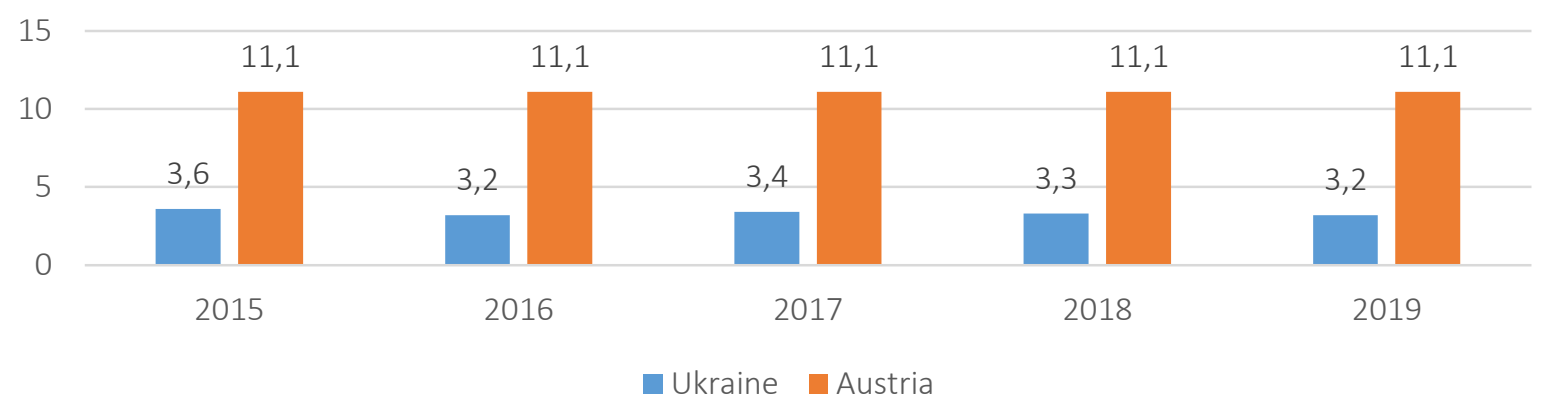

Note: * no data for share of expenditures of the population in general spending on health in Ukraine for 2019.

Figure 3. Healthcare state financing dynamics in Ukraine and Austria 2015-2019 
ta and determined benchmarks. An average share of expenditures of the population in general spending on health in Ukraine during the 2015-2019 years was at about 50\%. The existing gap could be reduced by the development of universal health. A key factor in making progress towards universal health coverage is public funding, and especially funding from state budgetary revenues (Sein, 2021). Globally, there is a strong inverse relationship between the share of government spending on GDP and the share of expenditures of the population in general spending on health. Nevertheless, successful reformation of the healthcare financing system in Ukraine depends on not only government spending but also mechanisms for pooling resources and improvement of the medical services efficiency.

\subsection{Overview of healthcare financing reforms in Ukraine and Austria}

After a development and approval strategy by the government in 2016, the parliament adopted a new Law of Ukraine "On State Financial Guarantees of Public Health Services" (№ 2168-VIII as of 19.10.2017), which regulates the financing of the healthcare system. Primary health care reforms include the design of a primary care benefits package, implementation of capitation-based payments, reimbursement of selected medicines based on an e-prescription and other novelties. The National Health Service of Ukraine (NHSU) was also established to launch strategic purchases of medical services specified in the guaranteed package (as a single purchaser). The reform aims to create a single national resource pool with a set of guaranteed entitlements to benefits for the whole population. Implementation of healthcare financing reform in Ukraine has successfully moved forward. During 2015-2019, the central government funded $77 \%$ of public health spending; the rest of the expenditures was financed by the local governments (World Health Organization \& The World Bank, 2019).

Since April 2020, Ukraine has fully launched the Program of Medical Guarantees and shifted health financing closer to universal health coverage. This program includes a list of health services and medicines guaranteed by the state; they are paid from the state budget using transparent mechanisms and unified tariffs through a consolidated electronic coding system. This ensures access to health services and prevents huge out-of-pocket expenses of patients (National Health Service of Ukraine, 2020).

Healthcare reform in Ukraine has changed the approach to the principles of healthcare financing. However, Ukraine has to spend up to $\$ 43.4$ billion per year additionally to build an efficient healthcare system (Malyovanyi et al., 2019). Implementing any SDG targets needs financial support; thus, the possible concepts should be also compared in the financial dimension (Brin \& Nehme, 2021; Buse \& Hawkes, 2015). From this perspective, successful EU experience can be very helpful to overcome the financing gap in public healthcare in Ukraine. Austria is one out of six countries worldwide that have incorporated SDGs in budget documentation (Sachs et al., 2019). In this context, Austria's experience as an EU-member country with a successful example of an SDG-financing strategy for the healthcare system can be used as an example for Ukraine.

Two major reforms of the healthcare system in Austria were implemented in 2013 and 2017. They aimed to develop and adopt the Austrian Health Targets. These Targets act as a guiding framework for health policy and ongoing reforms until 2032. Austrian Health Targets are adopted by the federal government and supported by different relevant stakeholders, which provides a common vision for the development of the healthcare system. The 2013 healthcare reform established a new target-based health governance system through a Federal Target-Based Governance Commission foundation. Since 2018, parts of the Austrian (federal level) and Regional Structural Plans (state level) for healthcare can be legally binding. Following a "Health in All Policies approach", Austrian Health Targets are detailed by intersectoral working groups into sub-targets (indicators), actions, and benchmarks (Bachner et al., 2018). Such an approach can be a good example of healthcare reform through an effective governance system aimed at strengthening mutual coordination and cooperation between government and self-governing organizations by promoting efficient decision-making, joint planning, and target-based financing. 


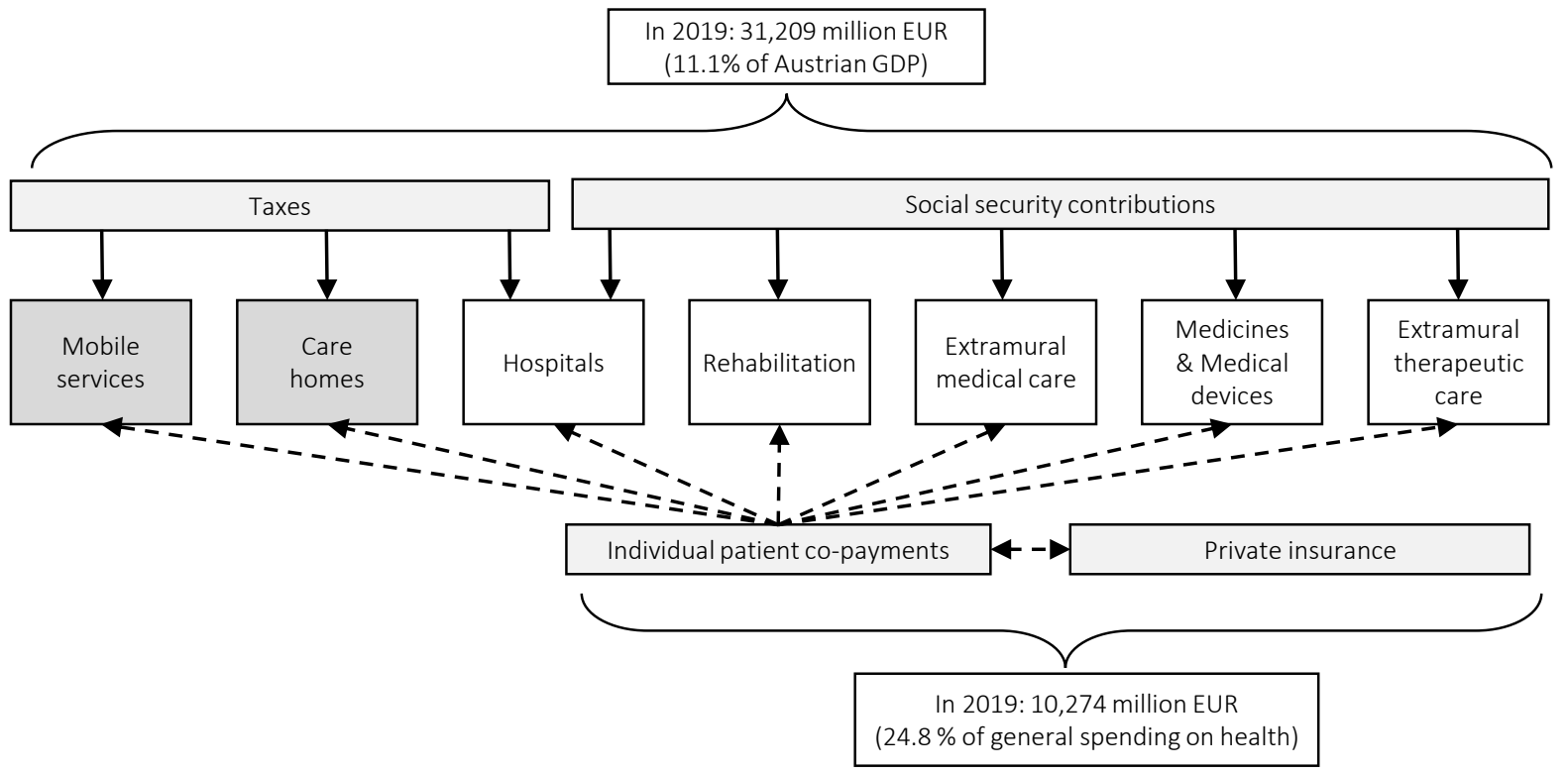

Figure 4. Financing sources of the Austrian healthcare system

Both Austrian and Ukrainian healthcare systems have four main sources of funding. These are taxes, social security contributions, benefits from private insurance, and individual co-payments by patients. A key difference between the two countries is in the proportion of these sources.

According to Bachner et al. (2018), the Austrian healthcare system is complex and includes the following dimensions: distribution of responsibilities between the federal and the state levels; delegation of responsibilities to self-governing bodies (social insurance funds and professional bodies of health service providers); mixed sources of healthcare financing from the state (federal and state levels) and social health insurance funds.

Figure 4 shows for which services the individual sources of financing are used in Austria. Taxes are primarily used for mobile services, care homes, and partly for the financing of hospitals. The compulsory contributions of patients (constituting the social security contributions), which are paid via the current salary and wage bill in the case of employed persons and via current advance payments in the case of self-employed persons, serve to finance all other health services in addition to the partial financing of hospitals. These expendi- tures account for approximately $11.1 \%$ of Austria's GDP (in comparison, in Ukraine this indicator is only $3.2 \%$ of the GDP). Taxes and social security contributions are classified as government expenditure according to statistics of the Federal Ministry of Social Affairs, Health, Care and Consumer Protection. In addition to these expenditures, self-payments of private households (approx. 7.332 million EUR) and benefits from privately concluded insurances (approx. 2,156 million EUR) are used to finance the healthcare system. A small part can still be attributed here to the categories of companies (approx. 94 million EUR), and private non-profit organizations (approx. 692 million EUR) (Bundesministerium für Soziales, Gesundheit, Pflege und Konsumentenschutz, 2021; Wirtschaftskammer Österreich, 2020). ${ }^{1}$

Income-related social health insurance contributions include about $60 \%$ of publicly financed health expenditure, while the remaining $40 \%$ is financed from taxation collected at the federal level, including value-added tax, income tax, taxes on tobacco (Bachner et al., 2018). The individual presentation of taxes and social contributions can at least indicate which financial tools are implicitly used (Statistik Austria, 2021). The following financing tools can be found under "Taxes":

1 These figures are based on the most recent information available for 2019. 
- Lotteries (Federal monopolies, gambling): 242 Mio. EUR

- Taxes on tobacco: 1,983 Mio. EUR

- Taxes on fuel (taxes on mineral oils): 3,579 Mio. EUR

Other taxes can be considered as possible financing tools given the goals of SDG 3 (e.g. taxes on pollution, tax on sparkling wine, etc.).

The study of the Austrian experience and national particularities of SDG 3 targets implementation allows to formulate general recommendations for policymakers in Ukraine:

- to unify the national system of SDG 3 targets and indicators in accordance with the global ones and strengthen the system of their monitoring;

- to include the SDG 3 targets in the national budget programs and strategies in healthcare, in particular by incorporating into national strategic documents and creating a general strategy for financing the achievement of SDG 3 (based on Austrian results-based financing);

- to study the Austrian experience on the distribution of responsibilities among different governing levels (mainstreaming approach);

- to continue to reform the healthcare system in Ukraine ensuring universal health coverage (target 3.8.1);

- to reduce the share of household expenditures in the total healthcare expenditures by creating a single transparent system of accounting for healthcare expenditures;

- to improve and promote the system of voluntary health insurance.

\subsection{Alternative financing tools for healthcare funding}

Taking into account the existing financing gap in SDG 3 funding, especially in low- and middle-income countries (e.g. Ukraine) it is crucial to search for alternative financing instruments. Efficient examples of such approaches were developed by the generally recognized international organizations such as the Financial Initiative for Biodiversity (BIOFIN) under the United Nations Development Program (UNDP) and the United States Agency for International Development (USAID). These organizations made a great contribution to global health funding. The new landscape of non-traditional approaches to global health financing applied by USAID includes the following financing tools: guarantee, debt swap, pooled investment funds, social insurance, seed funding, milestone-based payments, development income bonds, co-funding / global development alliance agreements (U.S. Agency for International Development, 2021).

According to the UNDP methodology, there is a wide range of recommended financing instruments on a responsible basis to achieve SDGs and in particular SDG 3: bioprospecting, impact investment, remittances (diaspora financing), taxes on pesticides and chemical fertilizers, crowdfunding, lotteries, results-based financing (social and development impact bonds), taxes on tobacco, environmental trust funds, payments for ecosystem services, taxes on fuel, voluntary standards (finance), public-private partnership (UNDP, 2020).

Prioritizing the above-mentioned financing tools according to the number of publications in the Scopus database (Table 6) indicates that not all of them are relevant in terms of healthcare financing.

Table 6 indicates that most of the publications in the Scopus database dedicated to healthcare financing approaches are covered by such instruments as social insurance, results-based financing, impact investment (including impact bonds), and public-private partnerships. Along with fiscal instruments, social insurance is one of the most common sources (in particular in both analyzed counties). That is why among other financial instruments in healthcare funding it possesses the first place by the number of publications in the Scopus database. The study of health spending in 133 countries (Wagstaff et al., 2020) indicates that the proportion of the population that is supposed to be covered by health insurance is a poor indicator of population financial protection. An increase 
Table 6. Prioritization of financing tools in healthcare according to the number of publications in the Scopus database as of July 10, 2021

Source: Authors' elaboration.

\begin{tabular}{|c|c|c|c|}
\hline \multirow{2}{*}{ № } & \multirow{2}{*}{ Financing tools } & \multicolumn{2}{|c|}{ Number of publications } \\
\hline & & Worldwide & In Europe \\
\hline 1 & Social insurance & 2112 & 655 \\
\hline 2 & Results-based financing & 729 & 342 \\
\hline 3 & Impact investment & 637 & 288 \\
\hline 4 & Public-private partnership & 327 & 113 \\
\hline 5 & Impact bonds & 154 & 68 \\
\hline 5.1 & Social and development impact bonds & 20 & 7 \\
\hline 6 & Lotteries & 80 & 34 \\
\hline 7 & Guarantee & 74 & 42 \\
\hline 8 & Taxes on tobacco & 40 & 13 \\
\hline 9 & Crowdfunding & 38 & 5 \\
\hline 10 & Seed funding & 21 & 5 \\
\hline 11 & Pooled investment funds & 8 & 5 \\
\hline 12 & Development income bonds & 11 & 8 \\
\hline 13 & Payments for ecosystem services & 10 & 1 \\
\hline 14 & Bioprospecting & 9 & 1 \\
\hline 15 & Environmental trust funds & 8 & 3 \\
\hline 16 & Milestone-based payments & 7 & 1 \\
\hline 17 & Taxes on fuel & 5 & 3 \\
\hline 18 & Voluntary standards (finance) & 4 & 2 \\
\hline 19 & Global development alliance agreements & 3 & 0 \\
\hline 20 & Taxes on pesticides and chemical fertilizers & 0 & 0 \\
\hline 21 & Debt swap & 0 & 0 \\
\hline 22 & Remittances (Diaspora financing) & 0 & 0 \\
\hline
\end{tabular}

of the GDP share spent on health is not enough to mitigate out-of-pocket health expenditures of the population; rather, what is required is an expansion of the share of prepaid health expenditure through taxes and mandatory contributions (Wagstaff et al., 2020). Thus, further research is needed to determine ways of social insurance improvement (in particular the case of Ukraine), taking into account the leading world and European experience.

According to Shroff (2017), over the last few years, a growing number of low- and middle-income countries have adopted results-based financing approaches for their healthcare sectors. Results-based financing describes healthcare financing approaches addressing both purchasing mechanisms and service quality to improve health outcomes. Moving from traditional input-based funding systems to results-based financing is suggested as a potential entry point to improve healthcare system performance and enable sound healthcare system transformation (Shroff et al., 2017).
Impact-investing is an effective tool for building socially responsible state investment policy. Recent studies describe key limitations of impact-investing development in the healthcare system of Ukraine, in particular: lack of generally accepted standards of transparency, impact management, and measurement; inadequate investment monitoring of projects; week executive discipline in the implementation of the impact-investing project; unformed system of benchmarks minimizing reputational risks; high transaction costs in the impact-investing market (Yelnikova \& Kwilinski, 2020). Impact bonds as a particular case of impact-investment have been seen as a potential tool to overcome certain barriers as they combine the competencies, experiences, and financial sources of different stakeholders to address social issues (Carè \& Lisa, 2019).

One of the listed instruments is public-private partnership, which is a tool for attracting private investment in a socially important healthcare sector that could be a mutually beneficial step for all participants. Based on Wang and Ma (2020), the 
relevance of public-private partnership for financing healthcare is very high because based on the literature review, it could be shown that most sustainability-oriented public-private partnership research is related to healthcare sector.

In Ukraine, the organizational and legal principles of interaction of public and private partners on a contractual basis are regulated by the Law of Ukraine "On Public-Private Partnership" №2404VI as of 01.07.2010. The Ministry of Healthcare of Ukraine has also established guidelines for state and municipal healthcare facilities for project implementation in public-private partnership in the field of healthcare (Ministry of Healthcare of Ukraine, 2018). The key problem of implementing the public-private partnership approach in Ukraine is the unpreparedness of municipal authorities to provide guarantees of funds' return to private partners (Popova et al., 2020).

The financing tools mentioned above can be used as an additional and alternative financing mechanism of healthcare funding in Ukraine that along with the improvement of the fiscal instruments, social security, and governance will level the risk of underfinancing and cut the existing financing gap to achieve SDG targets in healthcare.

\section{CONCLUSIONS}

National SDG 3 targets and indicators in Austria fully correspond to the global ones. At the same time, in Ukraine, the total number of indicators is much smaller and most national indicators in Ukraine correspond to global ones only partially. To enable efficient monitoring and focused target achievement, it is therefore advisable to fully align the national SDG 3 targets in Ukraine with the global ones.

In Austria, SDG 3 targets are completely incorporated into national strategic documents and are also explicitly mentioned in the budget documentation. In Ukraine, incorporation of SDG 3 targets is estimated at the low level; this means that the SDG 3 targets are isolated from other governmental and budgetary goals and therefore a coordinated achievement of goals between national and global SDG 3 goals is insufficient.

Key indicators of healthcare expenditures in Ukraine and Austria show a huge gap between analyzed countries. To improve the SDG 3 implementation in Ukraine based on the Austrian experience, general recommendations for policymakers in Ukraine were formalized. They cover such dimensions as the unification of the national system of SDG 3 targets and indicators in accordance with the global ones; strengthening and improving the system of their monitoring and governance; creation of a general strategy for financing the SDG 3 achievement following Austrian results-based financing approach. It is also necessary to continue the reformation of the healthcare system in Ukraine ensuring universal health coverage (target 3.8.1). This will reduce the share of household expenditures in the total healthcare expenditures and ensure the improvement of national well-being.

In order to cut the financing gap in SDG 3 funding in Ukraine, it is necessary to develop new sources of financial support for healthcare, which will help to attract private investment in the public health sector (for instance, the introduction of results-based financing, public-private partnership and impact investment in health).

\section{AUTHOR CONTRIBUTIONS}

Conceptualization: Inna Makarenko.

Data curation: Giuseppe Sorrentino.

Formal analysis: Mario Situm, Yuliia Serpeninova.

Investigation: Mario Situm.

Methodology: Inna Makarenko. 
Project administration: Alex Plastun.

Resources: Giuseppe Sorrentino.

Software: Yuliia Serpeninova.

Supervision: Alex Plastun.

Validation: Inna Makarenko.

Visualization: Giuseppe Sorrentino.

Writing - original draft: Mario Situm, Yuliia Serpeninova.

Writing - review \& editing: Alex Plastun.

\section{ACKNOWLEDGMENT}

This study is financed equally by the Austrian Federal Ministry of Education and Science and the Ministry of Education and Science of Ukraine.

\section{REFERENCES}

1. Abeykoon, P. (2021). Partnerships in health development. Journal of Health Management 23(1), 143-154. https://doi.org/10.1177\%2F0972063421995007

2. Bachner, F., Bobek, J., Habimana, K., Ladurner, J., Lepuschütz, L., Ostermann, H., Rainer, L., Schmidt, A. E., Zuba, M., Quentin, W., \& Winkelmann, J. (2018). Austria: Health system review. Health Systems in Transition, 20(3). Retrieved from https://jasmin. goeg.at/434/

3. Bali, S., \& Taaffe, J. (2017). The Sustainable Development Goals and the Global Health Security Agenda: Exploring synergies for a sustainable and resilient world. Journal of Public Health Policy, 38(2), 257-268. https://doi. org/10.1057/s41271-016-0058-4

4. Bennett, S., Jessani, N., Glandon, D., Qiu, M., Scott, K., Meghani, A., El-Jardali, F., Maceira, D., Javadi, D., \& Ghaffar, A. (2020). Understanding the implications of the sustainable development goals for health policy and systems research: Results of a research priority setting exercise. Globalization and Health, 16(1), 5. https://doi. org/10.1186/s12992-019-0534-2

5. Bhutta, Z. A., Siddiqi, S., Aftab, W., Siddiqui, F. J., Huicho, L., Mogilevskii, R., Mahmood, Q., Friberg, P., \& Akbari, F. (2020). What will it take to implement health and health-related sustainable development goals? British Medi- cal Journal Global Health, 5(9), e002963. https://doi.org/10.1136/ bmjgh-2020-002963

6. Brin, P., \& Nehme, M. (2021). Sustainable development in emerging economy: Using the analytical hierarchy process for corporate social responsibility decision making. Journal of Information Technology Management, 159174. https://dx.doi.org/10.22059/ jitm.2021.80744

7. Brolan, C. E., \& Hill, P. S. (2015). Countdown for health to the post-2015 UN Sustainable Development Goals. The Medical Journal of Australia, 202(6), 289291. Retrieved from https://www. mja.com.au/journal/2015/202/6/ countdown-health-post-2015-unsustainable-development-goals

8. Bundeskanzleramt. (2020). Österreich und die Agenda 2030: Freiwilliger Nationaler Bericht zur Umsetzung der Nachhaltigen Entwicklungsziele/SDGs (FNU). (In German). Retrieved March 24, 2021, from https://sustainabledevelopment.un.org/content/ documents/26661VNR_2020_ Austria_Report_German.pdf

9. Bundesministerium Finanzen. (2021). Bundesfinanzgesetz 2021. (In German). Retrieved June 11, 2021, from https://service.bmf. gv.at/Budget/Budgets/2021/bfg/ Bundesfinanzgesetz_2021.pdf

10. Bundesministerium für Soziales, Gesundheit, Pflege und Konsu- mentenschutz. (2021). Finanzierung des öffentlichen Gesundheitswesens. (In German). Retrieved June 11, 2021, from https://www. gesundheit.gv.at/gesundheitsleistungen/gesundheitswesen/finanzierung

11. Buse, K., \& Hawkes, S. (2015). Health in the sustainable development goals: Ready for a paradigm shirt? Globalization and Health, 11(1), 13. https://doi.org/10.1186/ s12992-015-0098-8

12. Carè, R., \& De Lisa, R. (2019). Social Impact Bonds for a Sustainable Welfare State: The Role of Enabling Factors. Sustainability, 11(10), 2884. https://doi. org/10.3390/su11102884

13. Cerf, M. E. (2019). Sustainable development goal integration, interdependence, and implementation: The environment-economic health nexus and universal health coverage. Global Challenges, 3(9), 1900021. https://doi.org/10.1002/ gch2.201900021

14. Chancel, L., Hough, A., \& Voituriez, T. (2018). Reducing inequalities within countries: Assessing the potential of the sustainable development goals. Global Policy, 9(1), 5-16. https:// doi.org/10.1111/1758-5899.12511

15. Christ, K. L., \& Burritt, R. L. (2019). Implementation of sustainable development goals: The role for business academics. Australian Journal of Management, 
44(4), 571-593. https://doi.org/10.1177\%2F0312896219870575

16. Development Initiatives. (2020). The cost achieving SDG 3 and SDG 4: How complete are financing estimates for the health and education goals? Retrieved May 20, 2021, from https://devinit.org/documents/716/The-cost-of-achievingSDG-3-and-SDG-4.pdf

17. Di Ruggiero, E. (2019). Health promotion in the sustainable development goal era. Global Health Promotion, 26(3), 3-4. https://doi.org /10.1177\%2F1757975919874708

18. Diaz-Sarachaga, J. M., Jato-Espino, D., \& Castro-Fresno, D. (2018). Is the sustainable development goals (SDG) index an adequate framework to measure the progress of the 2030 agenda? Sustainable Development, 26(6), 663-671. https:// doi.org/10.1002/sd.1735

19. Dieleman, J. L., Sadat, N., Chang, A. Y., Fullman, N., Abbafati, C., Acharya, P., Adou, A. K., Kiadaliri, A. A., Alam, K., AlizadehNavaei, R., Alkerwi, A., Ammar, W., Antonio, C. A. T., Olatunde Aremu, Asgedom, S. W., Atey, T. M., Avila-Burgos, L., Ayer, R., Badali, H., ... Murray, C. J. (2018). Trends in future health financing and coverage: future health spending and universal health coverage in 188 countries, 2016-40. The Lancet, 391(10132), 1783-1798. https://doi.org/10.1016/S01406736(18)30697-4

20. Doumbia, D., \& Lauridsen, M. L. (2019). Closing the SDG financing gap: Trends and data. EMCompass, 73, 1-8. Retrieved from http://hdl. handle.net/10986/32654

21. Fryatt, R., Bennett, S., \& Soucat, A. (2017). Health sector governance: Should we be investing more? British Medical Journal Global Health, 2(2). https://doi. org/10.1136/bmjgh-2017-000343

22. Griebler, R., Antony, G., Antosik, J., \& Delcour, J. (2010). Metaanalyse der Herausforderungen in der Umsetzung der Sustainable Development Goals in österreich Fokus Gesundheitsbereich. Vienna: Gesundheit Österreich. (In German).
23. Grynko, T., Shevchenko, T., Pavlov, R., Shevchenko, V., \& Pawliszczy, D. (2020). The impact of collaboration strategy in the field of innovation on the effectiveness of organizational structure of healthcare institutions. Knowledge and Performance Management, 4(1), 37-51. https://doi.org/10.21511/ kpm.04(1).2020.04

24. Guégan, J.-F., Suzán, G., KatiCoulibaly, S., Bonpamgue, D. N., \& Moatti, J.-P. (2018). Sustainable development goal \#3, "health and well-being", and the need for more integrative thinking. Veterinaria México OA, 5(2). https://doi. org/10.21753/vmoa.5.2.443

25. Horokhovets, Ye., Zhalilo, Ya., Kovalivska, S., Maksiuta, A., Nikolaiev, V., Marushevskyi, H., Onufryk, M., Prokip, A., Yakovenko, I., \& Maksiuta, A. (Ed.). (2017). Analysis of state strategic documents of Ukraine to take into account the Sustainable Development Goals for 2030 adapted for Ukraine. Institute of Socio-Economic Research. (In Ukrainian). Retrieved from https://www.ua.undp.org/ content/dam/ukraine/docs/ SDGreports/RIA_complete $\% 20$ report_ukr.pdf

26. International Bank for Reconstruction and Development \& The World Bank. (2019). High-performance health financing universal health coverage. Washington, DC: World Bank Publications.

27. Jamison, D. T., Alwan, A., Mock, C. N., Nugent, R., Watkins, D., Adeyi, O., Anand, S., Atun, R., Bertozzi, S., Bhutta, Z., Binagwaho, A., Black, R., Blecher, M., Bloom, B. R., Brouwer, E., Bundy, D., Chisholm, D., Cieza, A., Cullen, M., ... Zhao, K. (2018). Universal health coverage and intersectoral action for health: key messages from disease control priorities. The Lancet, 391(10125), 1108 1120. https://doi.org/10.1016/ S0140-6736(17)32906-9

28. Koilo, V. (2020). A methodology to analyze sustainable development index: evidence from emerging markets and developed economies. Environmental Economics, 11(1), 14-29. https://doi. org/10.21511/ee.11(1).2020.02
29. Le Blanc, D. (2015). Towards integration at last? The sustainable development goals as a network of targets. Sustainable Development, 23(3), 176-187. https://doi. org/10.1002/sd.1582

30. Lee, J., \& Kim, B. (2021). Social impacts of the continuous usage of digital healthcare service: A case of South Korea. Innovative Marketing, 17(2), 79-89. http://dx.doi. org/10.21511/im.17(2).2021.08

31. Malyovanyi, M., Prokopchuk, O., Lysa, N., Chernega, I., \& Malyovana, M. (2019). Evaluation of financing the health care system in Ukraine. Proceedings of the $33 \mathrm{rd}$ International Business Information Management Association Conference, IBIMA 2019: Education Excellence and Innovation Management through Vision 2020, 957-968.

32. Melnyk, L. G, Shkarupa, E. V, \& Kharchenko, M. O. (2013). Innovative strategies to increase economic efficiency of greening the economy. Middle East Journal of Scientific Research, 16(1), 30-37. Retrieved from https://www.idosi. org/mejsr/mejsr16(1)13/5.pdf

33. Melnyk, L., Dehtyarova, I., Kubatko, O., Karintseva, O., \& Derykolenko, A. (2019). Disruptive technologies for the transition of digital economies towards sustainability. Economic Annals-XXI, 179(9), 22-30. https:// www.ceeol.com/search/articledetail $? i d=851481$

34. Ministry of Economic Development, Trade and Agriculture of Ukraine, State Statistics Service of Ukraine, \& UNICEF in Ukraine. (2020). Sustainable Development Goals Ukraine 2019: Monitoring report. Retrieved March 24, 2021, from http://www.ukrstat.gov.ua/ csr_prezent/ukr/st_rozv/publ/ SDGs13.01.2020_engl.pdf

35. Ministry of Healthcare of Ukraine. (2018). Guidelines for state and municipal health care facilities, for employees of health authorities, for project implementation in public-private partnership in the field of health care. (In Ukrainian). Retrieved May 20, 2021, from https://moz.gov.ua/uploads/1/7840-1234567890.pdf 
36. Nabukalu, J. B., Asamani, J. A., \& Nabyonga-Orem, J. (2020). Monitoring sustainable development goals 3: Assessing the readiness of low- and middle-income countries. International Journal of Health Policy and Management, 9(7), 297-308. https://dx.doi. org/10.15171/ijhpm.2019.134

37. National Health Service of Ukraine. (2020). National health service of Ukraine: Annual report 2020. Retrieved March 24, 2021, from https://nszu.gov.ua/storage/ files/nhsu-annual-report-2020-enweb.pdf?1623857500

38. Nunes, A. R., Lee, K., \& O'Riordan, T. (2016). The importance of an integrating framework for achieving the sustainable development goals: The example of health and well-being. British Medical Journal Global Health, 1(3). https://doi.org/10.1136/bmjgh-2016-000068

39. Organisation for Economic Co-operation and Development. (n.d.). Policy coherence for sustainable development country profiles: Austria. Retrieved June 11, 2021, from https://www.oecd.org/gov/ pcsd/Country\%20Profile\%20Austria.pdf

40. Plastun, A., Makarenko, I., Grabovska, T., Situmeang, R., \& Bashlai, S. (2021). Sustainable Development Goals in agriculture and responsible investment: $\mathrm{A}$ comparative study of the Czech Republic and Ukraine. Problems and Perspectives in Management, 19(2), 65-76. https://doi. org/10.21511/ppm.19(2).2021.06

41. Popova, T., Iskiv, M., ZagurskaAntoniuk, V., Buryk, Z., Matsyk, V., \& Terentieva, N. (2020). The application of public-private partnership for the purpose of implementing state policy in the sphere of health care. International Journal of Economics and Business Administration, 8(3), 128-138. Retrieved from https://www.ijeba. com/journal/491

42. Sachs, J., Schmidt-Traub, G., Kroll, C., Durand-Delacre, D. \& Teksoz, K. (2017). SDG index and dashboards report 2017: Global responsibilities - international spillovers in achieving the goals. New York: Bertelsmann Stiftung and Sustainable Development Solutions Network (SDSN). Retrieved March 24, 2021, from https://s3.amazonaws. com/sustainabledevelopment.report/2017/2017_sdg_index_and_ dashboards_report.pdf

43. Sachs, J., Schmidt-Traub, G., Kroll, C., Lafortune, G., \& Fuller, G. (2019). Sustainable development report 2019: Transformation to achieve the sustainable development goals. New York: Bertelsmann Stiftung and Sustainable Development Solutions Network (SDSN). Retrieved March 24, 2021, from https://s3. amazonaws. com/sustainabledevelopment. report/2019/2019_sustainable_development_report.pdf

44. Sachs, J., Schmidt-Traub, G., Kroll, C., Lafortune, G., \& Fuller, G. (2018). SDG index and dashboards report 2018: Global responsibilities, implementing the goals. New York: Bertelsmann Stiftung and Sustainable Development Solutions Network (SDSN). Retrieved March 24, 2021, from under: https:// s3.amazonaws.com/sustainabledevelopment.report/2018/2018_sdg_ index_and_dashboards_report. pdf

45. Sachs, J., Schmidt-Traub, G., Kroll, C., Lafortune, G., Fuller, G., \& Woelm, F. (2020). Sustainable development report 2020: The sustainable development goals and Covid-19. Cambridge: Cambridge University Press. Retrieved March 24, 2021, from https:// s3.amazonaws.com/sustainabledevelopment.report/2020/2020_sustainable_development_report.pdf

46. Schmidt-Traub, G., \& Shah, A. (2015). Investment needs to achieve the sustainable development goals. Paris and New York: Sustainable Development Solutions Network.

47. Schwab, K. (2019). The global competitiveness report 2019. World Economic Forum. Retrieved June 30, 2021, from http://www3.weforum.org/docs/WEF_TheGlobalCompetitivenessReport2019.pdf

48. Sein, T. (2021). Generating financial resources for health. Journal of Health Management, 23(1),
47-53. https://doi.org/10.1177\% 2F0972063421995029

49. Shroff, Z. C., Tran, N., Meessen, B., Bigdeli, M., \& Ghaffar, A. (2017). Taking results-based financing from scheme to system. Health Systems \& Reform, 3(2), 69-73. Retrieved from https://www.rbfhealth.org/resource/taking-resultsbased-financing-scheme-system

50. Siddiqi, S., Aftab, W., Siddiqui, F. J., Huicho, L., Mogilevskii, R. Friberg, P., Lindgren-Garcia, J., Causevic, S., Khamis, A., Shah, M. M., \& Bhutta, Z. A. (2020). Global strategies and local implementation of health and health-related SDGs: Lessons from consultation in countries across five regions. British Medical Journal Global Health, 5(9), 1-9. Retrieved from https://gh.bmj.com/content/5/9/ e002859

51. Statistik Austria. (2020a). Ziel 03 - Gesundheit und Wohlergehen - Indikatoren. (In German). Retrieved May 15, 2021, from http://www.statistik.at/wcm/idc/ idcplg?IdcService=GET_PDF_FIL E\&RevisionSelectionMethod=Late stReleased\&dDocName $=115688$

52. Statistik Austria. (2020b). Agenda 2030 für nachhaltige Entwicklung in Österreich - SDG-Indikatorbericht. (In German). Retrieved March 24, 2021, from http:// www.statistik.at/wcm/idc/ idcplg?IdcService=GET_NATIVE_FILE\&RevisionSelectionM ethod=LatestReleased $\& \mathrm{dDocNa}$ me $=122802$

53. Statistik Austria. (2021). Österreichs Steuereinnahmen berechnet nach dem Europäischen System der Volkswirtschaftlichen Gesamtrechnungen (ESVG 2010). (In German). Retrieved March 24, 2021, from https://www.statistik. at/web_de/statistiken/wirtschaft/ oeffentliche_finanzen_und_ steuern/oeffentliche_finanzen/ steuereinnahmen/index.html

54. Stenberg, K., Hanssen, O., Edejer, T. T. T., Bertram, M., Brindley, C., Meshreky, A., Rosen, J. E., Stover, J., Verboom, P., Sanders, R., \& Soucat, A. (2017). Financing transformative health systems towards achievement of the health 
Sustainable Development Goals: A model for projected resource needs in 67 low-income and middle-income countries. The Lancet Global Health, 5(9), e875e887. https://doi.org/10.1016/ s2214-109x(17)30263-2

55. Tamsma, N., \& Costongs, C. (2018). Promoting health and well-being in the context of the United Nations Sustainable Development agenda. Scandinavian Journal of Public Health, 46(1), 44-48. https://doi.org/10.1177\% 2F1403494817741773

56. Theurl, E. (2019). Health expenditure and cost control in Austria. In Health Care and Cost Containment in the European Union (pp. 605633). Routledge.

57. United Nations Development Programme (UNDP). (2020). Goal 3: Good health and well-being. Retrieved March 24, 2021, from https://www.sdfinance.undp.org/ content/sdfinance/en/home/sdg/ goal-3--good-health-and-wellbeing.html

58. United Nations. (2016). Report of the inter-agency and expert group on sustainable development goal indicators: Note by the SecretaryGeneral. Retrieved May 20, 2021, from https://digitallibrary. un.org/record/821651/files/E_ CN.3_2016_2_Rev.1-EN.pdf
59. United Nations. (2020). Austria's voluntary national review - main messages. Retrieved July 16, 2021, from https://sustainabledevelopment.un.org/content/ documents/26134Austria_Main_ Messages_VNR.pdf

60. U.S. Agency for International Development. (2021). Investing for Impact Report. Retrieved July 16, 2021, from https://www.usaid.gov/ cii/investing-impact

61. Wagstaff, A., Flores, G., Hsu, J., Smitz, M. F., Chepynoga, K., Buisman, L. R., van Wilgenburg, K., \& Eozenou, P. (2018). Progress on catastrophic health spending in 133 countries: a retrospective observational study. The Lancet Global Health, 6(2), e169-e179. https://doi.org/10.1016/s2214109x(17)30429-1

62. Wang, N., \& Ma, M. (2020). Public-private partnership as a tool for sustainable development - What literatures say? Sustainable Development, 29(3), 243-258. Retrieved from https://onlinelibrary.wiley. com/doi/epdf/10.1002/sd.2127

63. Wirtschaftskammer Österreich. (2020). Laufende Gesundheitsausgaben 2019. (In German). Retrieved June 11, 2021, from https:// wko.at/statistik/Gesundheit/PDF/ Finaziers\%20d.Gesundheitsausg. pdf?_gl $=1^{\star} 1$ f7 yhri $^{*} \_g a^{*}$ MTI2
MDY0ODg0NS4xNjEwNzAwO DE2*_ga_4YHGVSN5S4*MTYyM zM5OTY3NS40LjAuMTYyMzM5 OTY3NS42MA..\&_ga=2.208035098.943458131.16233996761260648845.1610700816

64. World Health Organization \& The World Bank. (2019). Ukraine review of health financing reforms 2016-2019. Retrieved May 20, 2021, from https://www. euro.who.int/_data/assets/ pdf_file/0008/416681/WHO-WBJoint-Report_Full-report_Web.pdf

65. World Health Organization. (2020a). Budgetary space for the health care system in Ukraine. Retrieved March 24, 2021, from https://www.euro.who.int/_data/ assets/pdf_file/0003/463872/UKRBudgetary-space-for-health-ukr. pdf

66. World Health Organization. (2020b). World health statistics 2020: Monitoring health for the SDGs, sustainable development goals. Geneva: World Health Organization. Retrieved from https://apps.who.int/iris/handle/10665/332070

67. Yelnikova, J., \& Kwilinski, A. (2020). Impact-Investing in The Healthcare in Terms of the New Socially Responsible State Investment Policy. Business Ethics and Leadership, 4(3), 57-64. https://doi. org/10.21272/bel.4(3).57-64.2020 


\section{APPENDIX A}

Table A1. Correspondence of global and national SDG 3 targets in Austria and Ukraine

Source: Ministry of Economic Development, Trade and Agriculture of Ukraine et al. (2020).

\begin{tabular}{|c|c|}
\hline Global targets / National targets in Austria & National targets in Ukraine \\
\hline $\begin{array}{l}\text { 3.1. By } 2030 \text {, reduce the global maternal mortality ratio to less than } 70 \text { per } 100,000 \\
\text { live births. }\end{array}$ & 3.1. Reduce maternal mortality \\
\hline $\begin{array}{l}\text { 3.2. By } 2030 \text {, end preventable deaths of newborns and children under } 5 \text { years of age, } \\
\text { with all countries aiming to reduce neonatal mortality to at least as low as } 12 \text { per } \\
1,000 \text { live births and under- } 5 \text { mortality to at least as low as } 25 \text { per } 1,000 \text { live births }\end{array}$ & $\begin{array}{l}\text { 3.2. Minimize preventable mortality among } \\
\text { children under } 5\end{array}$ \\
\hline $\begin{array}{l}\text { 3.3. By } 2030 \text {, end the epidemics of AIDS, tuberculosis, malaria and neglected tropical } \\
\text { diseases and combat hepatitis, water-borne diseases and other communicable } \\
\text { diseases }\end{array}$ & $\begin{array}{l}\text { 3.3. End the epidemics of HIV/AIDS and } \\
\text { tuberculosis, including through innovative } \\
\text { practices and treatments }\end{array}$ \\
\hline $\begin{array}{l}\text { 3.4. By } 2030 \text {, reduce by one third premature mortality from non-communicable } \\
\text { diseases through prevention and treatment and promote mental health and } \\
\text { well-being }\end{array}$ & $\begin{array}{l}\text { 3.4. Reduce premature mortality from non- } \\
\text { communicable diseases }\end{array}$ \\
\hline $\begin{array}{l}\text { 3.5. Strengthen the prevention and treatment of substance abuse, including narcotic } \\
\text { drug abuse and harmful use of alcohol }\end{array}$ & - \\
\hline $\begin{array}{l}\text { 3.6. By } 2020 \text {, halve the number of global deaths and injuries from road traffic } \\
\text { accidents }\end{array}$ & $\begin{array}{l}\text { 3.6. Reduce serious injuries and deaths from } \\
\text { road traffic accidents }\end{array}$ \\
\hline $\begin{array}{l}\text { 3.7. By } 2030 \text {, ensure universal access to sexual and reproductive health-care services, } \\
\text { including for family planning, information and education, and the integration of } \\
\text { reproductive health into national strategies and programmes }\end{array}$ & - \\
\hline $\begin{array}{l}\text { 3.8. Achieve universal health coverage, including financial risk protection, access } \\
\text { to quality essential health-care services and access to safe, effective, quality and } \\
\text { affordable essential medicines and vaccines for all }\end{array}$ & $\begin{array}{l}\text { 3.7. Ensure universal, quality immunization with } \\
\text { innovative vaccines }\end{array}$ \\
\hline $\begin{array}{l}\text { 3.9. By } 2030 \text {, substantially reduce the number of deaths and illnesses from hazardous } \\
\text { chemicals and air, water and soil pollution and contamination }\end{array}$ & - \\
\hline $\begin{array}{l}\text { 3.a. Strengthen the implementation of the World Health Organization Framework } \\
\text { Convention on Tobacco Control in all countries, as appropriate }\end{array}$ & $\begin{array}{l}\text { 3.8. Reduce the prevalence of smoking among } \\
\text { the population through innovative media to } \\
\text { inform about negative effects of smoking }\end{array}$ \\
\hline $\begin{array}{l}\text { 3.b. Support the research and development of vaccines and medicines for the } \\
\text { communicable and non-communicable diseases that primarily affect developing } \\
\text { countries, provide access to affordable essential medicines and vaccines }\end{array}$ & - \\
\hline $\begin{array}{l}\text { 3.c. Substantially increase health financing and the recruitment, development, } \\
\text { training and retention of the health workforce in developing countries, especially in } \\
\text { least developed countries and small island developing States }\end{array}$ & 3.9. Reform health care financing \\
\hline $\begin{array}{l}\text { 3.d. Strengthen the capacity of all countries, in particular developing countries, for } \\
\text { early warning, risk reduction and management of national and global health risks }\end{array}$ & $\begin{array}{l}\text { 3.5. Reduce by a quarter premature mortality, } \\
\text { including through the introduction of innovative } \\
\text { approaches to diagnosing diseases }\end{array}$ \\
\hline
\end{tabular}

